A N N A L E S

UNIVERSITATIS MARIAE CURIE-SKŁODOWSKA

LUBLIN - POLONIA

VOL. XXXII, 4

SECTIO J

2019

Uniwersytet Opolski. Wydział Nauk Społecznych

\title{
PAWEŁ CIEŚLA
}

ORCID: 0000-0001-7127-7742

pawel.ciesla@uni.opole.pl

\section{Rodzinne determinanty wyborów edukacyjno-zawodowych $w$ świetle założeń teorii kolejności narodzin}

Family Conditions of Educational and Professional Choices Based on Birth Order Theory

\section{STRESZCZENIE}

W środowisku rodzinnym rozpoczyna się faktyczny proces preorientacji i wstępnej orientacji zawodowej. Poprzez wychowanie przez pracę i wprowadzanie dzieci w świat zawodów rodzice starają się przygotować młode osoby do podejmowania właściwych i trafnych wyborów edukacyjno-zawodowych wobec wymagań dynamicznie zmieniającego się rynku pracy. Celem prowadzonych badań była analiza uwarunkowań rodzinnych wyborów edukacyjno-zawodowych dzieci, w tym efektów kolejności narodzin jako czynnika formującego i różnicującego aspiracje oraz preferencje zawodowe przedstawicieli poszczególnych pozycji w rodzeństwie. W badaniach retrospektywnych prowadzonych metodą sondażu diagnostycznego przy użyciu autorskiego kwestionariusza ankiety wzięło udział 100 respondentów w wieku produkcyjnym, wywodzących się z rodzin wielodzietnych. W artykule przedstawiono najważniejsze postulaty odnoszące się do postaw rodzicielskich sprzyjających diagnozie i stymulacji predyspozycji zawodowych dzieci oraz do sposobów oddziaływania zawodowego rodziców względem poszczególnych dzieci. Uwagę zwrócono również na ocenę wsparcia rodzicielskiego w trakcie podejmowanych przez dzieci wyborów edukacyjno-zawodowych oraz na relacje między rodzeństwem, które powodują ujawnianie się pewnych specyficznych dla porządku narodzin cech osobowościowych, postaw i sposobów zachowań różnicujących ścieżki edukacyjno-zawodowe dzieci.

Słowa kluczowe: preorientacja zawodowa; wybory edukacyjno-zawodowe; postawy rodzicielskie; relacje między rodzeństwem; efekty kolejności narodzin 


\section{WPROWADZENIE}

Nadążanie za dynamicznie zmieniającym się rynkiem pracy w okresie niepewności zatrudnienia i akceleracji życia społecznego wymaga podejmowania przez uczniów świadomych wyborów edukacyjno-zawodowych, zgodnych z ich predyspozycjami zawodowymi i potrzebami rynku pracy. Aby wspomóc uczniów w kształtowaniu własnej wizji ścieżki edukacyjno-zawodowej, wprowadzono do szkół obligatoryjne zajęcia z zakresu doradztwa zawodowego, realizowane niezależnie od wsparcia $\mathrm{w}$ wyborze kierunku kształcenia, udzielanego w ramach wyspecjalizowanej pomocy psychologiczno-pedagogicznej (Ustawa z dnia 14 grudnia 2016 r. - Prawo oświatowe, art. 109 ust. 7). Zatrudnieni w szkołach doradcy zawodowi oferują uczniom wsparcie w kwestii diagnozy indywidualnych zasobów (zainteresowań, uzdolnień i cech osobowościowych przydatnych w środowisku pracy). Niemniej to właśnie w środowisku rodzinnym najwcześniej rozpoczyna się faktyczny proces wychowania przez pracę i preorientacji zawodowej (wstępnej informacji o świecie pracy i występujących zawodach), rzutujący na formowanie się aspiracji życiowych i zawodowych uczniów.

Dzieci, rozpoczynając planowanie ścieżki edukacyjno-zawodowej, szukają wsparcia przede wszystkim u rodziców (jako osób znaczących) w celu uzyskania rzetelnych informacji zawodoznawczych, porady bądź utwierdzenia w słuszności podjętych działań, co tylko potwierdza siłę oddziaływania rodziców na skonkretyzowanie przyszłego życia zawodowego młodego człowieka (Kargulowa, 2007, s. 98). Dlatego poprzez uwarunkowania rodzinne należy rozumieć wszelkie oddziaływania wychowawcze rodziców przyczyniające się w sposób bezpośredni lub pośredni do podejmowanych przez dzieci decyzji edukacyjno-zawodowych (wybór szkoły, kierunku kształcenia czy zawodu) (Pielka, 2000, s. 101). Jednym z tych oddziaływań, ukierunkowanych na odkrywanie i stymulowanie predyspozycji zawodowych, są niekiedy nieświadome postawy rodziców przyjmowane wobec poszczególnych dzieci, będące elementem założeń teorii kolejności narodzin.

W związku z powyższym celem niniejszego opracowania jest przybliżenie uwarunkowań rodzinnych w procesie przygotowania do wyborów edukacyjno-zawodowych dzieci o różnej kolejności narodzin. Przedstawione badania stanowią istotne uzupełnienie kwestii postaw rodzicielskich wobec wsparcia decyzyjnego dzieci w wieku szkolnym weryfikowanych przez Magdalenę Kamieniecką (2015, s. 23-25) pod kątem rozpoznawania obszarów deficytowych w przygotowaniu dzieci do podejmowania trafnych wyborów edukacyjno-zawodowych.

\section{ZAŁOŻENIA TEORII KOLEJNOŚCI NARODZIN W ZARYSIE}

Jako pierwszy na znaczenie kolejności pojawiania się dzieci w rodzinie w kształtowaniu osobowości uwagę zwrócił Alfred Adler. W efekcie swych rozważań sformułował tezę, że pierworodni synowie osiągają w życiu prywatnym 
i zawodowym więcej niż synowie urodzeni w dalszej kolejności, ponieważ aż do momentu narodzin kolejnego dziecka cała uwaga rodzicielska skupia się wyłącznie na nich, a komunikacja z rodzicami jest bogatsza pod względem językowym (Kosslyn, Rosenberg, 2006, s. 519). Spostrzeżenia Adlera stały się inspiracją dla Franka Sullowaya, który - analizując biografie przełomowych postaci historycznych w kontekście ich porządku narodzin - starał się dowiedzieć, dlaczego jedne osoby posiadały niebywałą zdolność do odrzucania obiegowych przekonan, rewolucjonizując społeczny sposób myślenia, podczas gdy inne konsekwentnie strzegły obowiązujących norm i zasad (Capodieci, 2006, s. 104-105).

Wychodząc z założenia o ograniczoności zasobów rodzicielskich zdatnych do rozdzielenia pomiędzy potomstwo, Sulloway sformułował teorię kolejności narodzin skoncentrowaną na opisie i wyjaśnieniu psychologicznych różnic w sferze osobowości i zachowań poszczególnych dzieci - zajmujących pozycję najstarszego (pierwszego), średniego (drugiego) i najmłodszego (trzeciego), konkurujących o uwagę i względy rodzicielskie (Lukasik, 2012, s. 50-51). Zgodnie z koncepcją teorii kolejności narodzin najstarszego w rodzeństwie cechuje: wyznaczanie sobie ambitnych celów, konserwatyzm, odpowiedzialność, dążenie do perfekcjonizmu, sumienność w wykonywaniu powierzonych zadań (Grose, 2003, s. 44). Środkowym w rodzeństwie przypisuje się wysokie kompetencje społeczne, w tym: skłonność do kompromisów, umiejętności mediacyjne pozwalające pogodzić zwaśnione strony, lojalność wobec przyjaciół, a jednocześnie niezależność, skrytość i podatność na presję zewnętrzną. Najmłodszych zaś w konstelacji rodzeństwa charakteryzuje m.in. skłonność do manipulacji, kreatywność, ostentacyjność, bycie czarującym, jak również buntowniczość czy skłonność do podejmowania ryzyka (Leman, 2009, s. 18).

Różnice w osobowości wynikają z rywalizacji o funkcjonujące w systemach rodzinnych tzw. nisze, czyli zespoły oczekiwanych przez rodziców ról i zadań (np. prymusa szkolnego, mediatora konfliktów rodzinnych), toteż kolejne dzieci zaczynają specjalizować się w różnorodnych zagadnieniach (odkrywanie ukrytych talentów i rozwijanie niekonwencjonalnej osobowości), pragnąc wyróżnić się na tle rodzeństwa i uzyskać aprobatę rodziców (Łukasik, 2012, s. 59). W efekcie przedstawiciele poszczególnych pozycji porządku narodzin, doświadczając zróżnicowanego środowiska rodzinnego, mogą realizować indywidualne strategie różnicujące ich przyszłe wybory, zarówno życiowe, jak i edukacyjno-zawodowe (Salmon, 2003, s. 85).

\section{ZAŁOŻENIA METODOLOGICZNE BADAŃ WŁASNYCH}

Postępowanie badawcze przeprowadzono metodą sondażu diagnostycznego wśród nieprobabilistycznie wyselekcjonowanych aktywnych zawodowo 100 osób w wieku produkcyjnym, wywodzących się z rodzin wielodzietnych (zapewniających prostą zastępowalność pokoleń). Konstrukcja autorskiego kwestionariusza 
ankiety umożliwiła pozyskanie danych związanych z subiektywnymi odczuciami przedstawicieli poszczególnych pozycji w rodzeństwie w wymiarze retrospektywnym (w trakcie podejmowania decyzji edukacyjno-zawodowych).

Prezentowane wyniki postepowania badawczego stanowią odpowiedź na pytania badawcze dotyczące: przejawianych przez rodziców postaw względem poszczególnych dzieci, związanych z procesem wychowania przez pracę; sposobów oddziaływania zawodowego rodziców w rodzinach wielodzietnych; oceny wsparcia rodzicielskiego w trakcie podejmowanych przez dzieci wyborów edukacyjno-zawodowych; korelacji pomiędzy kolejnością narodzin w rodzinie a dokonywanymi przez dzieci wyborami edukacyjno-zawodowymi.

\section{POSTAWY RODZICÓW WZGLĘDEM POSZCZEGÓLNYCH DZIECI A KWESTIA WYCHOWANIA PRZEZ PRACĘ}

Więź rodzinna stanowi kluczowy element kształtujący przyszłe wybory edukacyjno-zawodowe poszczególnych dzieci z rodzeństwa. To właśnie w środowisku rodzinnym kształtują się wyobrażenia i aspiracje dziecka dotyczące jego przyszłości zawodowej oraz ujawniają się pierwsze zdolności i zainteresowania, których stymulacja i prawidłowe ukierunkowanie wymagają od rodziców znacznych umiejętności zarówno wychowawczych, jak i doradczych, by możliwe było stopniowe wprowadzanie dzieci w świat pracy i zawodów występujących na rynku pracy (Łukasiewicz-Wieleba, Baum, 2013, s. 78).

Pozytywne postawy wychowawcze rodziców objawiają się przede wszystkim w zainteresowaniu i docenianiu dzieci w trakcie podejmowanych przez nich aktywności, ponieważ to je sytuuje w roli podmiotu, którego potrzeby są zauważane. Ponadto dyspozycyjność, cierpliwość i gotowość do wsparcia ich inicjatyw sprzyjają kształtowaniu wśród nich postaw nastawionych na sukces oraz wypracowaniu pozytywnego obrazu siebie i swych możliwości (Łukasiewicz-Wieleba, Baum, 2013, s. 21-23). Potwierdzeniem są wyniki badań. Otóż niezależnie od zajmowanej przez respondentów pozycji w porządku narodzin z ich wspomnień wynika, że rodzice dokładali wszelkich starań, aby w trakcie nadarzających się problemów rodzeństwo miało świadomość możliwości uzyskania od nich bezgranicznego wsparcia (tabela 1). Również w kwestii ujawniających się konfliktów będących immanentną cechą okresu dzieciństwa, gdyż większość z nich dotyczy sytuacji, z którymi każda jednostka zetknie się w przyszłym życiu zawodowym - rodzice interweniowali tylko w przypadkach nadmiernej eskalacji, pozwalając rodzeństwu na samodzielne wypracowywanie kompromisu (najstarsze - 84,4\%, średnie - 84,4\%, najmłodsze - 88,9\%).

Rodzice, wypełniając swoją funkcję wychowawczą, starają się traktować wszystkie dzieci jednakowo, ponieważ uważają, że pozwoli to uniknąć niepotrzebnej rywalizacji, konfliktów czy poczucia niesprawiedliwości. Strategia rów- 
Tabela 1. Stosunek rodziców do dzieci o różnej kolejności narodzin

\begin{tabular}{|c|c|c|c|c|c|c|c|c|c|c|c|c|}
\hline \multirow{3}{*}{$\begin{array}{l}\text { Postawy rodziców względem } \\
\text { dzieci }\end{array}$} & \multicolumn{4}{|c|}{$\begin{array}{l}\text { Najstarsze } \\
(\mathrm{N}=32)\end{array}$} & \multicolumn{4}{|c|}{$\begin{array}{l}\text { Średnie } \\
(\mathrm{N}=32)\end{array}$} & \multicolumn{4}{|c|}{$\begin{array}{l}\text { Najmłodsze } \\
(\mathrm{N}=36)\end{array}$} \\
\hline & \multicolumn{2}{|c|}{ tak } & \multicolumn{2}{|c|}{ nie } & \multicolumn{2}{|c|}{ tak } & \multicolumn{2}{|c|}{ nie } & \multicolumn{2}{|c|}{ tak } & \multicolumn{2}{|c|}{ nie } \\
\hline & $\mathrm{L}$ & $\%$ & L & $\%$ & $\mathrm{~L}$ & $\%$ & $\mathrm{~L}$ & $\%$ & $\mathrm{~L}$ & $\%$ & $\mathrm{~L}$ & $\%$ \\
\hline $\begin{array}{c}\text { Traktowali Was wszystkich } \\
\text { jednakowo? }\end{array}$ & 10 & 31,3 & 22 & 68,8 & 16 & 50,0 & 16 & 50,0 & 24 & 66,7 & 12 & 33,3 \\
\hline $\begin{array}{l}\text { Starali się łagodzić powstałe } \\
\text { pomiędzy Wami konflikty? }\end{array}$ & 27 & 84,4 & 5 & 15,6 & 27 & 84,4 & 5 & 15,6 & 32 & 88,9 & 4 & 11,1 \\
\hline $\begin{array}{c}\text { Obciążali wszystkich } \\
\text { z rodzeństwa równo } \\
\text { obowiązkami domowymi? }\end{array}$ & 13 & 40,6 & 19 & 59,4 & 15 & 46,9 & 17 & 53,1 & 20 & 55,6 & 16 & 44,4 \\
\hline $\begin{array}{c}\text { Ktoś z rodzeństwa zawsze } \\
\text { dostawał od rodziców to, } \\
\text { czego chciał? }\end{array}$ & 22 & 68,8 & 10 & 31,3 & 15 & 46,9 & 17 & 53,1 & 8 & 22,2 & 28 & 77,8 \\
\hline $\begin{array}{c}\text { Koncentrowali się na Twoich } \\
\text { problemach i starali się jak } \\
\text { najlepiej pomóc? }\end{array}$ & 22 & 68,8 & 10 & 31,3 & 20 & 62,5 & 12 & 37,5 & 28 & 77,8 & 8 & 22,2 \\
\hline $\begin{array}{c}\text { Stosowali krzywdzące } \\
\text { porównania pomiędzy wami? }\end{array}$ & 9 & 28,1 & 23 & 71,9 & 6 & 18,8 & 26 & 81,3 & 4 & 11,1 & 32 & 88,9 \\
\hline $\begin{array}{c}\text { Musiałeś(aś) rywalizować } \\
\text { z rodzeństwem o pozycję } \\
\text { i przywileje w rodzinie? }\end{array}$ & 15 & 46,9 & 17 & 53,1 & 13 & 40,6 & 19 & 59,4 & 3 & 8,3 & 33 & 91,7 \\
\hline $\begin{array}{c}\text { Miałeś(aś) poczucie bycia kimś } \\
\text { dodatkowym w rodzinie? }\end{array}$ & 4 & 12,5 & 28 & 87,5 & 8 & 25,0 & 24 & 75,0 & 5 & 13,9 & 31 & 86,1 \\
\hline
\end{tabular}

Źródło: opracowanie własne.

nego podziału zasobów rodzinnych w rzeczywistości prowadzi jednak do nierówności, gdyż dzieci instynktownie wyczuwają rozbieżności w obdarowywaniu ich dostępnymi zasobami rodzinnymi z uwagi na formułowane przez nie różne oczekiwania wobec rodziców. W efekcie, kierując się własnym interesem, starają się pozyskać dodatkowe zasoby, nawet kosztem rodzeństwa (Łukasik, 2012, s. 58).

Poczucie niesprawiedliwości w podziale rodzinnych zasobów uwidacznia się głównie w subiektywnych opiniach osób zajmujących pozycję środkowych (50\%) i najstarszych w rodzeństwie $(68,8 \%)$, którzy zgodnie z założeniami teorii kolejności narodzin przez pewien czas dysponowali wyłącznością uwagi i wsparcia rodzicielskiego, po czym stracili swą uprzywilejowaną pozycję na rzecz młodszego rodzeństwa, z czym najprawdopodobniej nie potrafili się pogodzić. Potwierdzeniem są także ich odpowiedzi dotyczące kwestii równości obciążania obowiązkami domowymi oraz poczucia faworyzacji, czyli obdarzania kogoś z rodzeństwa większą ilością dóbr rodzinnych - najprawdopodobniej osób zajmujących pozycję najmłodszego w rodzeństwie. Jednakże świadomość faworyzacji nie była 
przyczynkiem do rywalizacji pomiędzy rodzeństwem o dodatkowe przywileje ani nie budowała poczucia bycia kimś dodatkowym w rodzinie (tabela 1).

Innym negatywnym aspektem postaw rodzicielskich, zgodnie z teorią kolejności narodzin, są stosowane przez rodziców porównania pomiędzy dziećmi. Nawet gdyby intencją rodziców było sprawienie, by dziecko poczuło się wyjątkowo, zachęcenie do dalszych osiągnięć czy próba pocieszenia, to w rzeczywistości prowadzi to do zniekształcenia subiektywnego obrazu rodzeństwa. Stosowane porównania mogą destrukcyjnie oddziaływać na podejmowane przez poszczególne dzieci działania (np. twój brat w tym wieku miał już jasno sprecyzowane aspiracje edukacyjno-zawodowe), ponieważ zamiast skupić się na rozwoju swych predyspozycji, mogą skoncentrować się na sprostaniu oczekiwaniom formułowanym przez rodziców. Co najwyżej efektem porównań może być poczucie, że dziecko osadzone jest na tle rodzeństwa, a nie oceniane jako autonomiczna jednostka (Parker, Stimpson, 2003, s. 214-215). W odczuciu analizowanej populacji rodzice w przeważającej większości jednak nie stosowali krzywdzących porównań (najstarsze $-71,9 \%$, środkowe $-81,3 \%$, najmłodsze - $88,9 \%$ ), tym samym respektując i zaspokajając specyficzne potrzeby wynikające z pozycji w rodzeństwie.

Z perspektywy wczesnego zdiagnozowania obszarów zainteresowań dzieci, ich mocnych i słabych stron oraz podejmowania przez opiekunów adekwatnych działań zmierzających do rozwinięcia tych predyspozycji istotne są kwestie związane $\mathrm{z}$ wychowaniem przez pracę, rozpoczynające się $\mathrm{w}$ środowisku domowym kształtującym stosunek dziecka do pracy (Thier, 2013, s. 140).

Korzystając z dużej ruchliwości i aktywności dzieci w okresie dzieciństwa, należy przyjąć postawę gotowości wychodzenia naprzeciw ich potrzebom i ciekawości, inspirując do poznawania samych siebie, motywując i stwarzając im warunki do podejmowania nowych inicjatyw (Pisula, 2009, s. 80). Wychowanie przez pracę uwidacznia się $\mathrm{w}$ angażowaniu dzieci do prostych prac domowych pomagających im w ocenie własnych wysiłków i rozumieniu przyczyn niepowodzeń, ale przede wszystkim pozwala na nabycie nowych umiejętności, w tym na przyswojenie zasad rzetelnej pracy (np. sumienności, obowiązkowości, zdolności do rozwiazywania problemów, wytrwałości). Poprzez zwrócenie uwagi na edukację związaną z pracą przygotowuje się dzieci do przyszłego życia zawodowego, wzmacniając kształtowanie istotnych cech pracowniczych oraz pogłębiając zainteresowanie pracą i światem zawodów (Pielka, 2000, s. 98-99).

\section{SPOSOBY ODDZIAŁYWANIA ZAWODOWEGO RODZICÓW W RODZINACH WIELODZIETNYCH}

Charakter wykonywanej pracy oraz obrana ścieżka drogi zawodowej mogą mieć źródła w specyfice środowiska rodzinnego, szczególnie w oczekiwaniach rodziców - ich aspiracjach względem dzieci, stosunku do edukacji czy sukcesu 
w obszarze zawodowym. Rodzice jako nieprofesjonalni doradcy zawodowi poprzez wychowanie przez pracę wprowadzają dzieci w świat zawodów, pełniąc jednocześnie funkcję głównego źródła preorientacji i wstępnej orientacji zawodowej. Oddziaływania rodzicielskie w tym zakresie odnoszą się do zorientowania dzieci w sprawach dotyczących wyborów edukacyjno-zawodowych, czyli przygotowania ich do ,podejmowania świadomych decyzji w stosunku do dalszego kształcenia lub wyboru zawodu, zgodnie z własnym przygotowaniem i możliwościami” (Nowacki, Korabiowska-Nowacka, Baraniak, 1999, s. 175). Działania te realizowane są poprzez informowanie dzieci o zawodach występujących na lokalnym rynku pracy, opisywanie typowych czynności pracowniczych i warunków wykonywanej pracy, a także wskazywanie dróg prowadzących do zawodu.

Oddziaływania zawodowe rodziców w rodzinach wielodzietnych wpisywały się w proces preorientacji oraz wstępnej orientacji zawodowej. Rodzice poprzez rozmowy wprowadzali dzieci w świat zawodów występujących na rynku pracy (także tym lokalnym), informując m.in. o cechach psychofizycznych przydatnych w ich prawidłowym wykonywaniu - dotyczy to zwłaszcza potomstwa zajmującego pozycję najstarszego i najmłodszego w konstelacji rodzinnej (tabela 2). Opinie osób zajmujących środkową pozycję w rodzeństwie były podzielone, ponieważ nie wszyscy rodzice byli zainteresowani przekazywaniem im wiedzy zawodoznawczej $(48,3 \%)$, informowaniem o sytuacji na lokalnym rynku pracy $(37,5 \%)$ oraz poznaniem ich wizji przyszłości zawodowej $(25 \%)$ z uwagi na brak formułowanych wobec nich oczekiwań zawodowych i pozostawianie im większej swobody w kierowaniu własnym losem edukacyjno-zawodowym (71,9\%).

Rodzice zazwyczaj mają mniej lub bardziej sprecyzowane poglądy na temat przyszłości zawodowej swych dzieci, aczkolwiek najczęściej włączają je w proces podejmowania decyzji, czyniąc ich współodpowiedzialnymi za obraną drogę zawodową (Lukasiewicz-Wieleba, Baum, 2013, s. 91). W opinii rodziców pewne zawody są bardziej atrakcyjne od innych z uwagi na prestiż społeczny, gratyfikacje finansowe lub zawodowe tradycje rodzinne. Kontynuowanie zawodu rodziców może mieć wymiar pozytywny, kiedy dziecko świadomie podejmuje taką decyzję, bądź negatywny, gdy decyzja zawodowa podyktowana jest presją ze strony rodziców (Duda, Kukla, 2012, s. 34). Wówczas rodzice, zważając wyłącznie na własny system wartości, posiadane doświadczenie zawodowe i przeświadczenie o dziedziczności predyspozycji zawodowych, obligują dziecko do realizowania swojej ścieżki edukacyjno-zawodowej po wytyczonych przez nich śladach (np. rodziny prawnicze). W przeprowadzonych badanich rodzice jednak, niezależnie od zajmowanej przez dziecko pozycji w porządku narodzin, nie prezentowali poglądu o konieczności kontynuowania zawodowych tradycji rodzinnych (tabela 2).

Sytuacja materialna rodziców (szczególnie w rodzinach wielodzietnych) może być czynnikiem urealniającym ukształtowane zapatrywania zawodowe. Niektórych rodziców nie stać na pokrycie kosztów korepetycji, kursów języ- 
Tabela 2. Preorientacja i orientacja zawodowa w środowisku rodzinnym

\begin{tabular}{|c|c|c|c|c|c|c|c|c|c|c|c|c|}
\hline \multirow{3}{*}{$\begin{array}{l}\text { Sposoby oddziaływania } \\
\text { zawodowego rodziców }\end{array}$} & \multicolumn{4}{|c|}{ Najstarsze $(\mathrm{N}=32)$} & \multicolumn{4}{|c|}{ Średnie $(\mathrm{N}=32)$} & \multicolumn{4}{|c|}{ Najmłodsze $(\mathrm{N}=36)$} \\
\hline & \multicolumn{2}{|c|}{ tak } & \multicolumn{2}{|c|}{ nie } & \multicolumn{2}{|c|}{ tak } & \multicolumn{2}{|c|}{ nie } & \multicolumn{2}{|c|}{ tak } & \multicolumn{2}{|c|}{ nie } \\
\hline & $\mathrm{L}$ & $\%$ & $\mathrm{~L}$ & $\%$ & $\mathrm{~L}$ & $\%$ & $\mathrm{~L}$ & $\%$ & $\mathrm{~L}$ & $\%$ & $\mathrm{~L}$ & $\%$ \\
\hline $\begin{array}{c}\text { Rozmowa o zawodach } \\
\text { występujących na rynku } \\
\text { pracy }\end{array}$ & 21 & 65,6 & 11 & 34,4 & 14 & 43,8 & 18 & 56,3 & 23 & 63,9 & 13 & 36,1 \\
\hline $\begin{array}{c}\text { Liczy się ich zdanie } \\
\text { dotyczące Twojej } \\
\text { przyszłości zawodowej }\end{array}$ & 6 & 18,8 & 26 & 81,3 & 9 & 28,1 & 23 & 71,9 & 5 & 13,9 & 31 & 86,1 \\
\hline $\begin{array}{l}\text { Narzucenie kontynuacji } \\
\text { rodzinnych tradycji } \\
\text { zawodowych }\end{array}$ & 3 & 9,4 & 29 & 90,6 & 6 & 18,8 & 26 & 81,3 & 2 & 5,6 & 34 & 94,4 \\
\hline $\begin{array}{l}\text { Informowanie o zawodach } \\
\text { lokalnego rynku pracy }\end{array}$ & 18 & 56,3 & 14 & 43,8 & 12 & 37,5 & 20 & 62,5 & 18 & 50,0 & 18 & 50,0 \\
\hline $\begin{array}{c}\text { Wskazywanie przydatnych } \\
\text { cech i zestawu czynności } \\
\text { zawodowych }\end{array}$ & 21 & 65,6 & 11 & 34,4 & 11 & 34,4 & 21 & 65,6 & 14 & 38,9 & 22 & 61,1 \\
\hline $\begin{array}{l}\text { Urealnianie Twoich aspiracji } \\
\text { i oczekiwań zawodowych }\end{array}$ & 13 & 40,6 & 19 & 59,4 & 8 & 25,0 & 24 & 75,0 & 17 & 47,2 & 19 & 52,8 \\
\hline $\begin{array}{c}\text { Zachęcanie do dalszej nauki/ } \\
\text { doskonalenia }\end{array}$ & 25 & 78,1 & 7 & 21,9 & 20 & 62,5 & 12 & 37,5 & 21 & 58,3 & 15 & 41,7 \\
\hline
\end{tabular}

Źródło: opracowanie własne.

kowych czy dodatkowych zajęć rozwijających predyspozycje swoich pociech. Wówczas szanse na zdobycie wymarzonego wykształcenia i zawodu słabną, lecz wzrasta świadomość zawodowa, gdyż dziecko wybiera taką szkołę i taki zawód, które pozwolą mu się szybciej usamodzielnić i odciążyć finansowo rodziców (Duda, Kukla, 2012, s. 34).

Odnosząc się do danych empirycznych, należy stwierdzić, że rodzice starali się nie ingerować w zapatrywania zawodowe dzieci zajmujących pozycję najstarszego $(59,4 \%)$ i środkowego w rodzeństwie (75\%), lecz w przypadku dzieci najmłodszych $-\mathrm{z}$ uwagi na ich nieszablonowe podejście do życia i aktywności zawodowej - konieczne było urealnienie ich potencjalnych wyborów edukacyjno-zawodowych, zgodnie z możliwościami rodzinnymi (tabela 2). Warto podkreślić, że niezależnie od zajmowanej przez dziecko pozycji w porządku narodzin (najstarsze $-78,1 \%$, średnie $-62,5 \%$, najmłodsze $-58,3 \%$ ) rodzice starali się zachęcać je do dalszej nauki i doskonalenia, wierząc, że wyższy poziom wykształcenia, dodatkowe umiejętności lub specjalistyczne kwalifikacje pozwolą być bardziej konkurencyjnymi na rynku pracy. 


\section{RODZICIELSKIE WSPARCIE PODCZAS PODEJMOWANYCH PRZEZ DZIECI DECYZJI EDUKACYJNO-ZAWODOWYCH}

Charakteryzując uwarunkowania rodzinne w trakcie podejmowania wyborów edukacyjno-zawodowych, Elizabeth B. Hurlock wyróżniła trzy główne postawy rodzicielskie będące odzwierciedleniem ich oczekiwań i preferencji zawodowych względem drogi edukacyjno-zawodowej dzieci (Gałęska, 2013, s. 272-273), mianowicie:

- postawę dyrektywną, w której rodzice przejmują pełną odpowiedzialność za proces wyboru kierunku kształcenia czy zawodu dziecka, wynikającą z przeświadczenia o tym, że wiedzą najlepiej, jaka orientacja edukacyjno-zawodowa będzie najwłaściwsza względem predyspozycji zawodowych dzieci (wyraźny stosunek zależności i przyporządkowania na linii rodzice-dzieci),

- postawę liberalną, związaną z neutralnością rodziców wobec decyzji edukacyjno-zawodowych podejmowanych przez dzieci, która może przybierać dwa oblicza. W pierwszym rodzice uważają, że nie są na tyle kompetentni, by właściwie doradzać dziecku odnośnie do jego przyszłości, w drugim natomiast zapewniają pełne wsparcie emocjonalne, zostawiając jednocześnie dziecku pełną swobodę decyzyjną,

- postawę partnerską, ukierunkowaną na dialog i uznanie podmiotowości dziecka, które może „samodzielnie wybrać jakąś opcję, a w razie trudności zwrócić się do rodziców o pomoc i poradę" (Gałęska, 2013, s. 273). Zadaniem rodziców jest więc próba poszerzenia perspektyw zawodowych i alternatyw edukacyjnych dzieci przy braku krytycznego nastawienia wobec ich przyszłościowej wizji życiowej.

Umiejętności komunikacyjne rodziców dotyczą aktywnego słuchania, reagowania na potrzeby dziecka i wyjaśniania wszelkich niejasności związanych z rynkiem pracy czy ofertą edukacyjną. Oparte na dialogu aktywne współuczestniczenie rodziców w podejmowanych przez dzieci wyborach edukacyjno-zawodowych pomaga im w rozwijaniu właściwego wyobrażenia o sobie samym, zwiększa poczucie własnej wartości i utwierdza w słuszności przyjętej wizji zawodowej. Dzięki temu dziecko chce rozmawiać i dzielić się z rodzicami swoimi planami, a równolegle wysłucha ich opinii na temat alternatywnych ścieżek edukacyjnych czy zawodowych (Pielka, 2000, s. 101).

Propozycje edukacyjno-zawodowe rodziców w przeprowadzonym badaniu były ukierunkowane przede wszystkim na wyrażenie własnej opinii przy jednoczesnym pozostawieniu ostatecznej decyzji w gestii dziecka bądź na zasugerowanie zawodu, który ich zdaniem byłby najbardziej adekwatny wobec predyspozycji zawodowych dzieci lub stanowiłby ciekawą alternatywę (tabela 3). Celem tych propozycji była próba ochrony dzieci przed nie do końca świadomym i przemyślanym wyborem, szczególnie w odczuciu osób zajmujących pozycję najstarszego w rodzeństwie $(21,9 \%)$. 
Tabela 3. Rodzicielskie wsparcie podczas decyzji edukacyjno-zawodowych

\begin{tabular}{|c|c|c|c|c|c|c|}
\hline \multirow{2}{*}{ Cel edukacyjno-zawodowych propozycji rodziców } & \multicolumn{2}{|c|}{$\begin{array}{c}\text { Najstarszy } \\
(\mathrm{N}=32)\end{array}$} & \multicolumn{2}{|c|}{$\begin{array}{c}\text { Średni } \\
(\mathrm{N}=32)\end{array}$} & \multicolumn{2}{c|}{$\begin{array}{c}\text { Najmłodszy } \\
(\mathrm{N}=36)\end{array}$} \\
\cline { 2 - 9 } & $\mathrm{L}$ & $\%$ & $\mathrm{~L}$ & $\%$ & $\mathrm{~L}$ & $\%$ \\
\hline $\begin{array}{c}\text { Wskazać zawód najbardziej odpowiadający } \\
\text { Twoim predyspozycjom }\end{array}$ & 7 & 21,9 & 5 & 15,6 & 3 & 8,3 \\
\hline $\begin{array}{c}\text { Wywołanie refleksji nad uprzednio podjętymi wyborami } \\
\text { zawodowymi }\end{array}$ & 1 & 3,1 & 3 & 9,4 & 0 & 0,0 \\
\hline $\begin{array}{c}\text { Realizacja własnych niespełnionych aspiracji } \\
\text { zawodowych }\end{array}$ & 5 & 15,6 & 4 & 12,5 & 1 & 2,8 \\
\hline Ochrona przed nieprzemyślanym wyborem zawodowym & 7 & 21,9 & 2 & 6,3 & 4 & 11,1 \\
\hline Ukazanie ciekawej alternatywy zawodowej & 0 & 0,0 & 3 & 9,4 & 5 & 13,9 \\
\hline Wyrażenie własnej opinii, pozostawiając & 7 & 21,9 & 6 & 18,8 & 6 & 16,7 \\
\hline swobodę wyboru & 5 & 15,6 & 9 & 28,1 & 17 & 47,2 \\
\hline Brak propozycji zawodu ze strony rodziców
\end{tabular}

Źródło: opracowanie własne.

Negatywne oddziaływanie rodziców było związane z krytykowaniem decyzji dzieci i zniechęcaniem oraz sugerowaniem, aby wystrzegały się pewnych zawodów. W ten sposób ukierunkowywano je na realizację niespełnionych marzeń i ambicji rodzicielskich (tabela 3 ). W planach rodziców związanych z przyszłością zawodową dzieci (nawet jeśli nie są artykułowane wprost) odzwierciedlają się ich oczekiwania zawodowe wynikające z możliwości ,sięgnięcia po to, czego sami pragnęli w przeszłości, a czego mieć nie mogli” (Duda, Kukla, 2012, s. 36). Jeśli są one tożsame z zainteresowaniami i możliwościami dziecka, wówczas stają się dobrym motywatorem do działania, w przeciwnym wypadku jednak mogą stać się obciążeniem powodującym wewnętrzną frustrację i poczucie bezradności, negatywnie oddziałując na rozwój osobowości. Warto podkreślić, że oczekiwania i aspiracje rodziców ( $w$ tym propozycje zawodowe) różnią się także w zależności od pozycji, jaką dziecko zajmuje wśród rodzeństwa. Zazwyczaj mniej oczekuje się od najmłodszych $(47,1 \%)$ i średnich $(28,1 \%)$ dzieci - nie wywiera się na nich silnej presji osiągnięć tak, jak w przypadku najstarszych z rodzeństwa $(15,6 \%)$ (Richardson, Richardson, 2001, s. 107).

\section{KOLEJNOŚĆ NARODZIN A WYBORY EDUKACYJNO-ZAWODOWE}

Rodzinne uwarunkowania decyzji edukacyjno-zawodowych nie tylko są determinowane przez postawy i sposoby odziaływania zawodowego rodziców, lecz także są rozpatrywane jako rezultat relacji między rodzeństwem. Stosunki między rodzeństwem przepełnione są pewną ambiwalencją: od wzajemnej rywalizacji i konfliktów stymulujących dywersyfikację zainteresowań (nisza rodzinna) do 
współpracy i przyjaźni. Wykształcenie pewnych cech osobowościowych, postaw czy zachowań $\mathrm{w}$ toku interakcji z rodzeństwem odciska trwałe piętno na przyszłych wyborach zawodowych (preferencjach zawodowych) z uwagi na chęć wyróżnienia się na tle rodzeństwa i uzyskania pochwały od rodziców.

Tabela 4. Ujawnianie się efektów kolejności narodzin podczas sytuacji typowych dla okresu dzieciństwa

\begin{tabular}{|c|c|c|c|c|c|c|}
\hline \multirow{2}{*}{$\begin{array}{l}\text { Efekty kolejności narodzin w sytuacjach typowych } \\
\text { dla okresu dzieciństwa }\end{array}$} & \multicolumn{2}{|c|}{$\begin{array}{c}\text { Najstarszy } \\
(\mathrm{N}=32)\end{array}$} & \multicolumn{2}{|c|}{$\begin{array}{c}\text { Średni } \\
(\mathrm{N}=32)\end{array}$} & \multicolumn{2}{|c|}{$\begin{array}{l}\text { Najmłodszy } \\
(\mathrm{N}=36)\end{array}$} \\
\hline & L & $\%$ & L & $\%$ & $\mathrm{~L}$ & $\%$ \\
\hline $\begin{array}{c}\text { Bawiłem(am) się z rówieśnikami, ale wyłącznie na moich } \\
\text { warunkach }\end{array}$ & 2 & 6,3 & 4 & 12,5 & 4 & 11,1 \\
\hline $\begin{array}{c}\text { Podczas zabaw uwielbiałem(am) wcielać się w mediatora } \\
\text { i rozwiązywać konflikty }\end{array}$ & 5 & 15,6 & 7 & 21,9 & 3 & 8,3 \\
\hline $\begin{array}{l}\text { Zawsze przestrzegałem(am) zasad obowiązujących } \\
\text { podczas gry }\end{array}$ & 20 & 62,5 & 13 & 40,6 & 15 & 41,7 \\
\hline $\begin{array}{l}\text { Lubiłem(am) łamać określone odgórnie zasady } \\
\text { gier czy zabaw }\end{array}$ & 2 & 6,3 & 5 & 15,6 & 8 & 22,2 \\
\hline $\begin{array}{l}\text { Podczas wspólnych zabaw przyjmowałem(am) } \\
\text { pozycję lidera grupy }\end{array}$ & 8 & 25,0 & 7 & 21,9 & 4 & 11,1 \\
\hline $\begin{array}{c}\text { Starałem(am) się być odpowiedzialny(a) za młodszych } \\
\text { towarzyszy zabaw }\end{array}$ & 18 & 56,3 & 14 & 43,8 & 9 & 25,0 \\
\hline $\begin{array}{c}\text { Łatwo ulegałem(am) rozczarowaniu, jeśli coś mi nie } \\
\text { wyszło podczas zabawy }\end{array}$ & 4 & 12,5 & 6 & 18,8 & 13 & 36,1 \\
\hline $\begin{array}{l}\text { Uwielbiałem(am) ponosić ryzyko podczas zabaw, by } \\
\text { zaimponować innym }\end{array}$ & 3 & 9,4 & 6 & 18,8 & 12 & 33,3 \\
\hline Potrafiłem(am) dobrze zorganizować przebieg zabawy & 17 & 53,1 & 6 & 18,8 & 8 & 22,2 \\
\hline Łatwo ulegałem(am) presji rówieśników & 5 & 15,6 & 12 & 37,5 & 13 & 36,1 \\
\hline $\begin{array}{l}\text { Potrafiłem }(\text { am) wykorzystać swoją wyobraźnię } \\
\text { i kreatywność w toku gier i zabaw }\end{array}$ & 12 & 37,5 & 16 & 50,0 & 19 & 52,8 \\
\hline
\end{tabular}

Uwaga: wyniki nie sumują się do 100\%, gdyż osoby badane miały wskazać trzy najczęściej przejawiane zachowania w okresie dzieciństwa

Źródło: opracowanie własne.

Krytyka założeń koncepcji Sullowaya dotyczy tezy, iż efekty kolejności narodzin nie pozostawiają trwałych śladów w osobowości, będąc wyłącznie obrazem środowiska domowego - w innym środowisku porzucane są domowe strategie zachowania (Harris, 1998, s. 81-82). Tymczasem powyższe dane empiryczne potwierdzają, że przyjmowane postawy i zachowania są w pewnym stopniu odzwierciedleniem strategii wypracowanych $\mathrm{w}$ toku interakcji $\mathrm{z}$ rodzeństwem w okresie dzieciństwa (tabela 4).

Najstarsze $\mathrm{z}$ rodzeństwa $\mathrm{w}$ trakcie sytuacji typowych dla okresu dzieciństwa zgodnie z założeniami teorii kolejności narodzin umiejętnie organizowały 
przebieg wspólnych zabaw $(53,1 \%)$, przestrzegając wcześniej ustalonych zasad $(62,5 \%)$ oraz przyjmując pozycję lidera $(25 \%)$. Pierworodni stanowili surogat rodziców dla swojego młodszego rodzeństwa, nad którym sprawowali opiekę w trakcie wspólnych zabaw przejmowali odpowiedzialność nad młodszymi towarzyszami (56,3\%) (por. Łukasik, 2012, s. 59).

Wspominając wspólne zabawy z okresu dzieciństwa, przedstawiciele środkowej pozycji w porządku narodzin (podobnie jak najstarsi) przestrzegali ustalonych zasad (40,6\%) i dążyli do przejmowania opieki nad młodszymi towarzyszami $(43,8 \%)$. Jakkolwiek z drugiej strony ujawniła się ich podatność na presję ze strony otoczenia oraz niebywała zdolność do mediacji i rozwiązywania nadarzających się problemów, wynikające $\mathrm{z}$ ich zorientowania na utrzymywanie pozytywnych relacji z obojgiem rodzeństwa (Richardson, Richardson, 2001, s. 153).

$\mathrm{Z}$ kolei najmłodsi $\mathrm{z}$ rodzeństwa $\mathrm{w}$ trakcie wspólnych zabaw zgodnie z teorią Sullowaya ujawniali skłonności do podejmowania ryzykownych działań (33,3\%), starając się przestrzegać obowiązujących zasad, co pozostawało jednak w sprzeczności z ich naturą do kontestacji zastanego porządku. Ponadto, pomimo wykorzystywania swej kreatywności pozwalającej im spostrzegać zwykłe rzeczy w niezwykły sposób (Richardson, Richardson, 2001, s. 130), łatwo ulegali rozczarowaniu, jeśli podejmowane działania nie pozwalały osiągnąć zamierzonego celu $(36,1 \%)$.

\section{ZAKOŃCZENIE}

Podejmowanie decyzji edukacyjno-zawodowych z uwagi na konieczność funkcjonowania w ramach współczesnego, nieprzewidywalnego i dynamicznie zmieniającego się rynku pracy wymaga od rodziców wczesnego rozpoczęcia procesu preorientacji i wstępnej orientacji zawodowej.

Rodzice, stopniowo wprowadzając dzieci w świat pracy, przejawiali pozytywne nastawienie wobec zainteresowań i preferencji zawodowych dzieci ujawniających się w toku wspólnych zabaw czy wykonywania obowiązków domowych. Starali się wspierać podejmowane przez dzieci inicjatywy, sytuując je w roli podmiotu, którego indywidualne potrzeby są zauważane. Jednakże dążąc do równego traktowania, nieświadomie przyczyniali się do poczucia niesprawiedliwości wśród dzieci, które chciały wyróżnić się na tle rodzeństwa.

Sposoby oddziaływania zawodowego rodziców związane były przede wszystkim z inicjowaniem rozmów z dziećmi na temat ich przyszłości edukacyjno-zawodowej. Poprzez dialog rodzice starali się skonkretyzować ich wizje zawodowe, przekazując informacje o występujących na rynku pracy zawodach odpowiadających ich predyspozycjom zawodowym. Ponadto starali się zachęcać dzieci do dalszej nauki i rozwoju prozawodowego, ufając, że umożliwi im to w przyszłości lepszy start życiowy. 
Interakcje rodziców z dziećmi cechowała postawa partnerska, umożliwiająca ukształtowanie w nich wiary we własne możliwości sprawcze oraz świadomości uzyskania wsparcia niezależnie od podejmowanych decyzji. Dzieci nieskrępowanie mogły zwrócić się do rodziców o pomoc w urealnieniu swych aspiracji zawodowych, utwierdzeniu w słuszności podjętych samodzielnie decyzji - wiedziały, że rodzice nie wykorzystają swej uprzywilejowanej pozycji, aby skrytykować ich zapatrywania zawodowe.

Ujawniające się $\mathrm{w}$ toku interakcji z rodzeństwem psychologiczne różnice w osobowości dzieci, wynikające z poszukiwania niezajętej niszy w systemie rodzinnym, stawały się stymulatorem działalności dzieci także w innych środowiskach. W efekcie wykształcone cechy osobowościowe i przyjmowane postawy różnicowały aspiracje i preferencje zawodowe poszczególnych dzieci, rzutując jednocześnie na podejmowane przez nie wybory edukacyjno-zawodowe.

Rozważania teoretyczne oraz uzyskane wyniki empiryczne mogą stanowić podstawę do sformułowania praktycznych wskazówek dla rodziców chcących wesprzeć swoje dzieci w podejmowaniu trafnych decyzji edukacyjno-zawodowych. Rodzinne determinanty wyborów edukacyjno-zawodowych odnoszą się zarówno do postaw rodziców względem poszczególnych dzieci, jak i ich wzajemnych stosunków. Warto pamiętać, że stosowanie choćby przypadkowych porównań między rodzeństwem prowadzi często do nieświadomej faworyzacji powodującej poczucie niesprawiedliwości i polaryzującej relację między nimi. Każda pozycja w rodzeństwie wymaga od rodziców indywidualnego podejścia i zrozumienia jej odmienności. W związku z tym nie należy za wszelką cenę zmierzać do równego traktowania swych pociech, ponieważ nieświadomie można zniwelować uwidaczniające się w postaci cech osobowościowych, postaw czy zachowań tzw. efekty kolejności narodzin. Taka postawa rodzicielska może niekorzystnie oddziaływać na przyszły społeczny podział pracy oraz na dopasowanie indywidualnych predyspozycji dzieci w kontekście wymagań zawodów występujących na rynku pracy.

Przyjmując rolę nieprofesjonalnych doradców zawodowych, rodzice powinni w miarę jak najszybciej rozpocząć w środowisku domowym proces wychowania przez pracę w ramach preorientacji zawodowej. Poprzez stworzenie odpowiedniego klimatu, pozwalającego dzieciom na podejmowanie różnorodnych inicjatyw, możliwe jest wczesne rozpoznanie zainteresowań i preferencji prozawodowych poszczególnych dzieci. Poświęcając uwagę i zainteresowanie wszystkim dzieciom, doceniając podejmowane przez nie wysiłki, oferując swoje wsparcie pozbawione krytyki, można we właściwym kierunku wzmacniać ich predyspozycje edukacyjno-zawodowe i wiarę we własne możliwości.

Oczywiście obiektywna ocena zainteresowań i uzdolnień dzieci bywa niezwykle trudna i niejednokrotnie kończy się wysunięciem propozycji wyboru kierunku kształcenia lub zawodu przewyższającego ich potencjalne możliwości. 
Co istotne, wsparciem w prawidłowej diagnozie predyspozycji zawodowych dzieci mogą być zajęcia $\mathrm{z}$ zakresu doradztwa zawodowego realizowane w szkołach publicznych przez specjalistów z rynku pracy (Ustawa z dnia 14 grudnia $2016 \mathrm{r}$. - Przepisy wprowadzające ustawę - Prawo oświatowe, art. 292 ust. 1-2). Dzięki profesjonalnej pomocy uczeń kończący dany etap edukacji powinien posiadać dostateczną wiedzę pozwalającą na podjęcie właściwej, trafnej i samodzielnej decyzji edukacyjno-zawodowej, uwzględniającej własne zainteresowania, predyspozycje zawodowe, a także potrzeby rynku pracy.

\section{BIBLIOGRAFIA}

Capodieci, S. (2006). Rodzeństwo - Jaś i Matgosia czy Kain i Abel. Warszawa: Instytut Wydawniczy Pax.

Duda, W., Kukla, D. (2012). Rodzice jako podstawowy determinant wyborów edukacyjno-zawodowych dzieci. Doradca Zawodowy, 1(14), 32-39.

Gałęska, U. (2013). Rola rodziny w wyborach edukacyjno-zawodowych młodzieży. Wychowanie $w$ Rodzinie, 8, 267-282.

Grose, M. (2003). Why First Borns Rule the World and Last Borns Want to Change It. North Sydney: Random House Australia.

Harris, J.R. (1998). Geny czy wychowanie? Co wyrośnie z naszych dzieci i dlaczego. Warszawa: Wydawnictwo Jacek Santorski \& Co.

Kamieniecka, M. (2015). Decyzje edukacyjno-zawodowe uczniów szkót gimnazjalnych. Raport podsumowujacy. Warszawa: Instytut Badań Edukacyjnych.

Kargulowa, A. (2007). O teorii i praktyce poradnictwa. Odmiany poradoznawczego dyskursu. Podręcznik akademicki. Warszawa: Wydawnictwo Naukowe PWN.

Kosslyn, S.M., Rosenberg, R.S. (2006). Psychologia: mózg, człowiek, świat. Kraków: Społeczny Instytut Wydawniczy Znak.

Leman, K. (2009). The Birth Order Book: Why You Are the Way You Are. Grand Rapids: Revell a division of Baker Publishing Group.

Łukasiewicz-Wieleba, J., Baum, A. (2013). Rodzicielskie sposoby rozpoznawania i rozwijania zainteresowań i zdolności. Warszawa: Wydawnictwo Akademii Pedagogiki Specjalnej.

Łukasik, A. (2012). Psychologiczne i społeczne konsekwencje ewolucyjnego konfliktu rodzice-potomstwo. Psychologia Rozwojowa, 17(1), 49-64,

DOI: https://doi.org/10.4467/20843879PR.12.004.0379.

Nowacki, T.W., Korabiowska-Nowacka, K., Baraniak, B. (1999). Nowy słownik pedagogiki pracy. Warszawa: Wydawnictwo Wyższej Szkoły Pedagogicznej Towarzystwa Wiedzy Powszechnej.

Parker, J., Stimpson, J. (2003). Rodzeństwo - rywalizacja i miłość. Wszystko, co powinni wiedzieć rodzice braci i sióstr. Poznań: Dom Wydawniczy Rebis.

Pielka, H. (2000). Rodzina - wybór zawodu - szkoła. Roczniki Socjologii Rodziny, 12, 97-105.

Pisula, D. (2009). Poradnictwo kariery przez cate życie. Warszawa: Krajowy Ośrodek Wspierania Edukacji Zawodowej i Ustawicznej. 
Richardson, R.W., Richardson, L.A. (2001). Najstarsze, średnie, najmłodsze. Jak kolejność narodzin wpływa na twój charakter. Gdańsk: GWP.

Salmon, C.A. (2003). Birth order and relationships: family, friends and sexual partners. Human Nature, 14(1), DOI: https://doi.org/10.1007/s12110-003-1017-x.

Thier, A. (2013). Preorientacja zawodowa dziecka - zaniedbana podstawa sukcesu zawodowego. W:

B. Balogová, M. Skyba, D. Šoltésová (red.), Pregraduálna príprava sociálnych pracovníkov, pracovničok a sociológov, sociologičiek a možnosti ich uplatnenia v prax (s. 140-151). Prešov: Prešovská univerzita v Prešove.

Ustawa z dnia 14 grudnia 2016 r. - Prawo oświatowe (Dz.U. 2017, poz. 59).

Ustawa z dnia 14 grudnia 2016 r. - Przepisy wprowadzające ustawę - Prawo oświatowe (Dz.U. 2017, poz. 60).

\section{SUMMARY}

The actual process of pre-orientation and initial profession orientation starts in the family environment. Thought upbringing by work and introduction of the children to the world of professions parents are trying to prepare young people to make right and accurate choices in the area of education and profession according to dynamically changing work market. The aim of the study was to approximate family conditions, including the meaning of birth order effect as a factor forming aspirations and preferences of individual children. In the retrospective research with the use of own diagnostic survey, there were questioned a 100 people in the production age, which come out of large families. The article presents the major postulates referring to parental attitudes, which are friendly to development work predispositions as well as ways parents influence on individual children. Highlighted is also the level of parental attitudes, during undertaking by their children educational and professional choices, as well as the relation between siblings, which shows some specific for the birth order personal values, and actions which differ the educational and work paths of children.

Keywords: profession pre-orientation; educational and professional choices; parental attitudes; sibling relationship; birth order effect 